\title{
Induction of Ski Protein Expression upon Luteinization in Rat Granulosa Cells without a Change in its mRNA Expression
}

\author{
Hyun KIM ${ }^{1)}$, Keitaro YAMANOUCHI'), Takashi MATSUWAKI') and Masugi NISHIHARA ${ }^{1)}$ \\ 1) Department of Veterinary Physiology, Graduate School of Agricultural and Life Sciences, The University of Tokyo, Tokyo \\ 113-8657, Japan
}

\begin{abstract}
The Ski protein is implicated in the proliferation/differentiation of a variety of cells. We previously reported that the Ski protein is present in granulosa cells of atretic follicles, but not in preovulatory follicles, suggesting that Ski has a role in apoptosis of granulosa cells. However, granulosa cells cannot only undergo apoptosis but can alternatively differentiate into luteal cells. It is unknown whether Ski is expressed and has a role in granulosa cells undergoing luteinization. Thus, the aim of the present study was to determine the localization of the Ski protein in the rat ovary during luteinization to examine if Ski might play a role in this process. In order to examine the Ski protein expression during the progression of luteinization, follicular growth was induced in immature female rats by administration of equine chorionic gonadotropin, and luteinization was induced by human chorionic gonadotropin treatment to mimic the luteinizing hormone (LH) surge. While no Ski-positive granulosa cells were present in the preovulatory follicle, Ski protein expression was induced in response to the LH surge and was maintained after formation of the corpus luteum (CL). Although the Ski protein is absent from the granulosa cells of the preovulatory follicle, its mRNA (c-ski) was expressed, and the level of c-ski mRNA was unchanged even after the LH surge. The combined results demonstrated that Ski protein expression is induced in granulosa cells upon luteinization, and suggested that its expression is regulated posttranscriptionally.
\end{abstract}

Key words: Arkadia, Granulosa cells, Luteinization, Ski

(J. Reprod. Dev. 58: 254-259, 2012)

O varian folliculogenesis and luteinization in mammals is a complex series of events that is regulated by endocrine and paracrine/autocrine factors. The role of the endocrine factors, gonadotropins, follicle stimulating hormone (FSH) and luteinizing hormone $(\mathrm{LH})$, in regulating folliculogenesis and luteinization is well established. Gonadotropin is an important survival factor for developing follicles that allows their escape from atresia and stimulates early antral follicles to complete their final differentiation and reach the preovulatory follicle stage. A preovulatory follicle responds to the LH surge by embarking on a terminal differentiation pathway termed "luteinization" that transforms granulosa and theca cells of a preovulatory follicle into luteal cells that form the corpus luteum (CL). Luteinizing follicular cells undergo specific morphological and biochemical changes, as well as endocrinological alterations, in their transition to luteal cells [1,2]. Many genes that are highly expressed in growing preovulatory follicles are turned off by the LH surge, whereas the expression of numerous genes that are involved in ovulation and luteinization increases dramatically during the periovulatory period $[3,4]$.

The effects of gonadotropins are mediated or regulated by a number of paracrine/autocrine growth factors [5, 6]. For example, members of the transforming growth factor- $\beta$ (TGF- $\beta$ )

Received: August 20, 2011

Accepted: December 13, 2011

Published online in J-STAGE: January 25, 2012

C 2012 by the Society for Reproduction and Development

Correspondence: K Yamanouchi (e-mail: akeita@mail.ecc.u-tokyo.ac.jp) family are expressed by oocytes, granulosa cells and theca cells in a developmental-stage dependent manner and play roles in the proliferation/atresia of granulosa/theca cells, steroidogenesis, oocyte maturation, ovulation and luteinization [7-9]. Some of the TGF- $\beta$ receptor family downstream signaling molecules (Smads) and binding proteins (follistatin) are also expressed in the ovary, and function in follicular development and luteinization [10, 11].

The signaling pathway of the TGF- $\beta$ family has been shown to be negatively regulated by Ski, the protein that is encoded by the proto-oncogene $c$-ski [12-16], via its interactions with Smad proteins [17-19]. The $c$-ski gene has been identified as the cellular homologue of $v$-ski, which was originally identified as the transforming gene of the avian Sloan-Kettering viruses, which transform chicken embryonic fibroblasts, leading to their morphological transformation and anchorage-independent growth [12-16]. In addition to its transforming activity, $c$-ski is known to induce myogenic differentiation of quail embryonic cells [12]. Thus, $c-s k i$ has been suggested to have dual roles in the cell, regulating both transformation (proliferation) and differentiation of cells.

We previously showed that Ski is present in granulosa cells of atretic follicles in the rat ovary, whereas it is absent from granulosa cells of preovulatory follicles [20]. Since the TGF- $\beta$ family plays important roles during luteinization, it is highly likely that Ski is involved in this process. Thus, the aim of the present study was to investigate the possible involvement of Ski in luteinization. For this purpose, we used immunohistochemical techniques to examine Ski protein expression in rat ovaries during ovulation and subsequent CL formation using the equine chorionic gonadotropin 
(eCG)/human chorionic gonadotropin (hCG)-primed rat model.

\section{Materials and Methods}

\section{Animals and sample preparation}

Immature (25-day-old) female Wistar-Imamichi rats were purchased from the Imamichi Institute of Animal Reproduction (Ibaraki, Japan). Synchronized folliculogenesis was initiated by administration of eCG (40 IU, s.c.) followed by hCG (15 IU, s.c.) to induce ovulation and subsequent luteinization [21]. In this model, ovulation occurs at around $12 \mathrm{~h}$ after hCG injection [22]. The rats were euthanized by cervical dislocation, and ovaries were collected at the time points indicated $(n=3-4$ animals per time point). After removal of connective tissues, ovaries were embedded in the OCT compound (Sakura Finetek, Tokyo, Japan) and stored at $-80 \mathrm{C}$ until use. For examination of gene expression using real-time PCR, granulosa cells were collected from the ovary and immediately used for RNA isolation. At each time point, blood samples were also collected, and the sera were separated and stored at $-20 \mathrm{C}$. Atretic follicles were obtained from hypophysectomized (HPX) female rats at $96 \mathrm{~h}$ after eCG treatment. All animals received humane care according to the Guide for the Care and Use of Animals of The University of Tokyo.

\section{Hormone assay}

Serum concentrations of progesterone and estradiol-17 $\beta$ were measured using estradiol enzyme-immunoassay kits (Cayman Chemical, Ann Arbor, MI, USA), according to the manufacturer's protocol.

\section{Immunohistochemistry and TUNEL staining}

Immunohistochemical analyses of Ski were performed as described previously [20]. In brief, frozen tissue sections (5 $\mu \mathrm{m}$ thick) prepared from the OCT-embedded rat ovary using a cryostat (Microm HM550, Carl Zeiss Japan, Tokyo, Japan) were mounted on glass slides, fixed in $4 \%$ paraformaldehyde (PFA) in phosphate bufferedsaline (PBS) for $20 \mathrm{~min}$ and then incubated in $0.1 \%$ Triton $\mathrm{X}-100$ in PBS for $15 \mathrm{~min}$. The sections were then immersed in blocking solution (8\% skim milk in PBS) for $30 \mathrm{~min}$. The primary rabbit anti-Ski antibody (Santa Cruz Biotechnology, Santa Cruz, CA, USA; 1:100 in 5\% normal goat serum (NGS) in PBS) was applied and incubated for $60 \mathrm{~min}$. After several washes with PBS, the sections were then incubated with Alexa Fluor-conjugated secondary antibody (Invitrogen, Carlsbad, CA, USA; diluted 1:200 in 5\% NGS in PBS) for $60 \mathrm{~min}$. Nuclei were counterstained with Hoechst 33258. The sections were observed under a fluorescent microscope (BX50, Olympus, Tokyo, Japan) equipped with a digital camera (DP70, Olympus). The percentages of Ski-positive cells amongst only granulosa cells within the luteinizing follicle and all the cells within the corpus luteum were calculated.

For double-staining of Ski and TUNEL-positive cells, the sections were fixed in 4\% PFA in PBS for $30 \mathrm{~min}$, followed by incubation in $0.1 \%$ Triton X-100 in PBS for $15 \mathrm{~min}$. The sections were incubated in methanol for $30 \mathrm{~min}$ and then immersed in blocking solution $(8 \%$ skim milk in PBS) for $30 \mathrm{~min}$. The primary anti-Ski antibody was applied and incubated for $90 \mathrm{~min}$. The sections were then incubated with Alexa Fluor-conjugated secondary antibody (Invitrogen) for 60 min. DNA fragmentation was subsequently detected using a commercial kit (In Situ Cell Detection Kit, Fluorescein, Roche, Penzberg, Germany). The slides were rinsed with PBS and incubated with permeabilization solution $(0.1 \%$ Triton $\mathrm{X}-100$ in $0.1 \%$ sodium citrate) for $2 \mathrm{~min}$ on ice. The slides were then incubated with TdT (Fluorescein, green color) for $60 \mathrm{~min}$ at $37 \mathrm{C}$. The sections were observed under a fluorescent microscope (BX50, Olympus) equipped with a digital camera (DP70, Olympus).

\section{qPCR (real-time PCR)}

Granulosa cells were obtained at $0,3,6$ and $12 \mathrm{~h}$ after hCGinjection by puncturing the large preovulatory follicles with a 27-gauge needle. The cells were washed with PBS and immediately used for RNA isolation.

Total RNA was isolated using TRIzol reagent (Invitrogen), and cDNA was synthesized with SuperScript II (200 U/ml) using an oilgo-dT 16 primer. qPCR was performed using LightCycler (Roche Diagnostics GmbH, Mannheim, Germany) and the LightCycler FastStart Thunderbird SYBR qPCR Mix (Toyobo, Osaka, Japan) according to the manufacturer's instructions. The primer sequences used were as follows: rat c-ski (forward primer, 5'-CAGCAGATCAACTCGGTGTG-3'; reverse primer, 5'-AGGATGCCCATGACTTTGAG-3'), rat arkadia (forward primer, 5'-CGTGAGGAGAACTGCATCAA-3'; reverse primer, 5'- GGATGTGCTAATGCATGCTG-3') and rat HPRT (forward primer, 5'-GACCGGTTCTGTCATGTCG-3'; reverse primer, 5'-ACCTGGTTCATCATCACTAATCAC -3'). Rat-specific primers were designed using the Primer3 software (available at http:// fokker.wi.mit.edu/primer3/), and the specificity of each primer set was confirmed by both electrophoresis of the PCR products and by analysis of the melting (dissociation) curve after each qPCR. No amplification occurs when these primers are used for PCR against rat genomic DNA under the conditions below. The reaction solution $(20 \mu \mathrm{l})$ consisted of $2 \mu \mathrm{l}$ of the template (the appropriate dilution for each gene was determined), $10 \mu$ of LightCycler FastStart Thunderbird SYBR qPCR Mix, $1 \mu$ of each primer $(10 \mu \mathrm{M})$ and $3 \mu$ of diethylpyrocarbonate-treated water. PCR amplification was performed as follows: predenaturation for one cycle at $95 \mathrm{C}$ for 15 min followed by 45 cycles of $95 \mathrm{C}$ for $15 \mathrm{sec}, 59 \mathrm{C}$ for $20 \mathrm{sec}$ and $72 \mathrm{C}$ for $30 \mathrm{sec}$. Melting curve analysis was performed at $65-95$ $\mathrm{C}$ with $0.1 \mathrm{C} / \mathrm{sec}$ temperature transition, and quantification was done by standardcurve analysis.

\section{Statistical analysis}

Statistical analyses were conducted using StatView (version J5, SAS Institute Inc., Berkeley, CA, USA). One-way analysis of variance and Dunnett's test were used to determine differences between the groups. Differences were considered statistically significant at $\mathrm{P}<0.05$.

\section{Results}

To investigate the possible involvement of Ski during luteinization, Ski was immunohistochemically analyzed in ovarian sections obtained from rats having a single generation of CLs. Consistent 
A

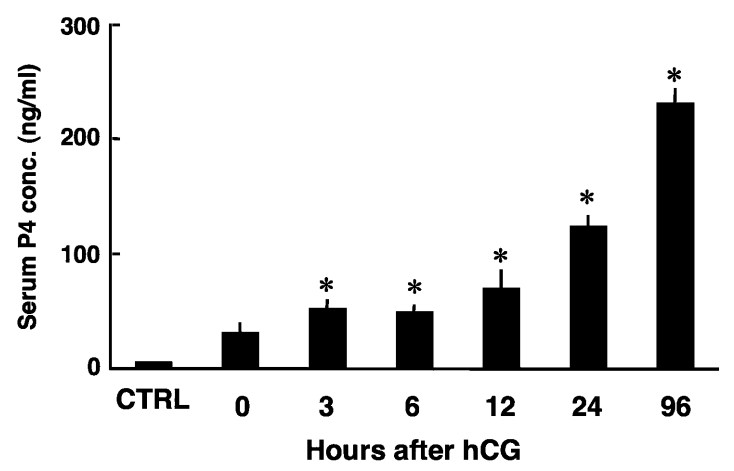

B

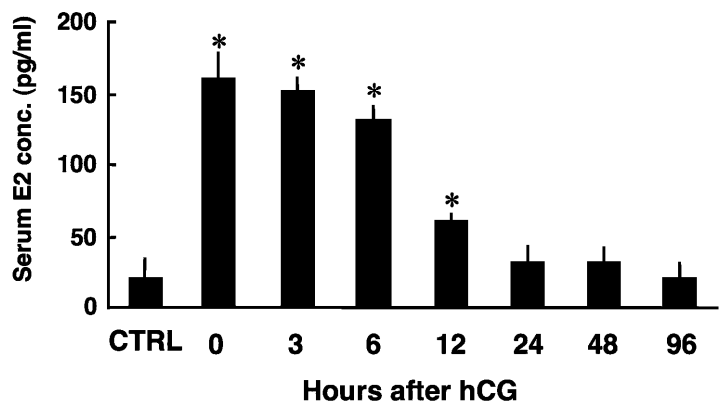

Fig. 1. Establishment of a rat model with a single generation of CLs. Rats were treated with eCG (40 IU, s.c.) followed by hCG (15 $\mathrm{IU}$, s.c.). At the indicated times after hCG administration, progesterone (P4) (A) and serum estradiol-17ß (E2) concentrations (B) were determined. CTRL, control (without hormonal treatment). The data are means \pm SE (3-4 rats were used at each time point). *: $\mathrm{P}<0.05$ vs. CTRL.

with previous reports [23], serum progesterone concentrations were increased after hCG-treatment, indicating that hCG treatment successfully induced ovulation and luteinization (Fig. 1A). Serum estradiol concentrations were higher in the rats treated with eCG only or primed with $\mathrm{eCG} / \mathrm{hCG}$ than in the control (without hormonal treatment) rats until $12 \mathrm{~h}$ after $\mathrm{hCG}$ injection (Fig. 1B). Thereafter, the estradiol concentration decreased to a level comparable to that in control rats, which reflects decreased aromatase activity due to initiation of luteinization (Fig. 1B). These results indicate that treatment with eCG followed by hCG successfully established a rat model having a single generation of CLs.

We next immunohistochemically analyzed Ski expression in ovarian sections from these eCG/hCG-treated rats. As shown in Fig. 2A, Ski was expressed in luteinizing granulosa cells at 6 and $12 \mathrm{~h}$ after hCG injection, while no Ski-positive granulosa cells were found in preovulatory follicles ( $0 \mathrm{~h}$ in Fig. $2 \mathrm{~A})$. Ski expression persisted after formation of the CL ( $96 \mathrm{~h}$ after hCG) (Fig. 2A). Quantitative analysis of these data revealed that the percentage of cells that were Ski-positive at $24 \mathrm{~h}$ or later after hCG injection was significantly higher than that at earlier time points (before $12 \mathrm{~h}$ ) (Fig. 2B). Since ovulation is expected to occur in this rat model at around $12 \mathrm{~h}$, this result suggests that the number of Ski-positive cells increases after ovulation.

We previously reported that the Ski protein is expressed in granulosa cells of atretic follicles [20]. In order to determine if the
Ski-positive cells that appeared after hCG treatment were the cells that were undergoing apoptosis, we analyzed apoptosis of these cells using a TUNEL assay. No apoptotic cell death was detected during luteinization even though Ski-positive cells were present (Fig. 3). On the other hand, numerous TUNEL-positive cells were observed in atretic follicles that were formed following HPX + eCG treatment and that also contained Ski-positive cells (Fig. 3). The combined results indicate that Ski-positive cells do not undergo apoptosis during CL formation, and suggested that Ski expression is induced in granulosa cells upon luteinization after LH surge.

In order to determine if $c$-ski expression is under the control of $\mathrm{LH}$, luteinizing granulosa cells were obtained from eCG/hCG-primed rats before ovulation, and their expression of $c$-ski mRNA was determined using qPCR. C-ski mRNA was detected in granulosa cells even before hCG injection, and its expression level was unchanged after hCG injection (Fig. 4A), indicating that $c$-ski mRNA expression in granulosa cells is not regulated during luteinization. This result raised the possibility that the cellular level of the Ski protein is regulated at the translational and/or posttranslational level and not at the transcriptional level, during luteinization.

Nagano et al. [24] recently reported that knockdown of Arkadia, an E3 ubiquitin ligase, abrogated TGF- $\beta$-induced degradation of the Ski protein, demonstrating that Arkadia is responsible for degradation of the Ski protein. In order to determine if Arkadia might possibly be involved in regulation of the Ski protein during luteinization, the mRNA expression level of Arkadia during luteinization of granulosa cells was assessed using qPCR. However, as shown in Fig. 4B, the level of Arkadia mRNA expression was unchanged during luteinization.

\section{Discussion}

The results of the present study demonstrated that the Ski protein is expressed in luteinizing granulosa cells and in cells within the $\mathrm{CL}$ and that its expression is induced in response to LH surge.

The present study suggested that the number of Ski-positive cells increases after ovulation. During luteinization, the steroidogenic granulosa and theca cells differentiate into luteal steroidogenic cells, and, upon ovulation, other nonsteroidogenic cell populations such as fibroblasts, endothelial, blood and immune cells migrate extensively into the newly formed CL. These nonsteroidogenic cells have been shown to be essential for luteinization and for maintenance of CL function [37-45]. Amongst these nonsteroidogenic cells, macrophages are known to produce cytokines and chemokines that regulate luteal cell function [43]. In this regard, it should be noted that Ski has been shown to be present in macrophages [46]. Ueki et al. demonstrated Ski-PU.1 interaction is critical for Ski's ability to repress PU.1-dependent transcription and block differentiation of macrophages [46]. Thus, it is possible that Ski may have negative roles in macrophages that are associated with angiogenesis and production of cytokines and chemokines during CL formation.

The process of luteinization is considered to be under the control of luteinization inhibitors, which are thought to prevent rapid luteinization and suppress progesterone synthesis until the oocyte is released at ovulation [8]. Granulosa cells secrete activin, which stimulates granulosa cell proliferation in preantral/early antral 
A

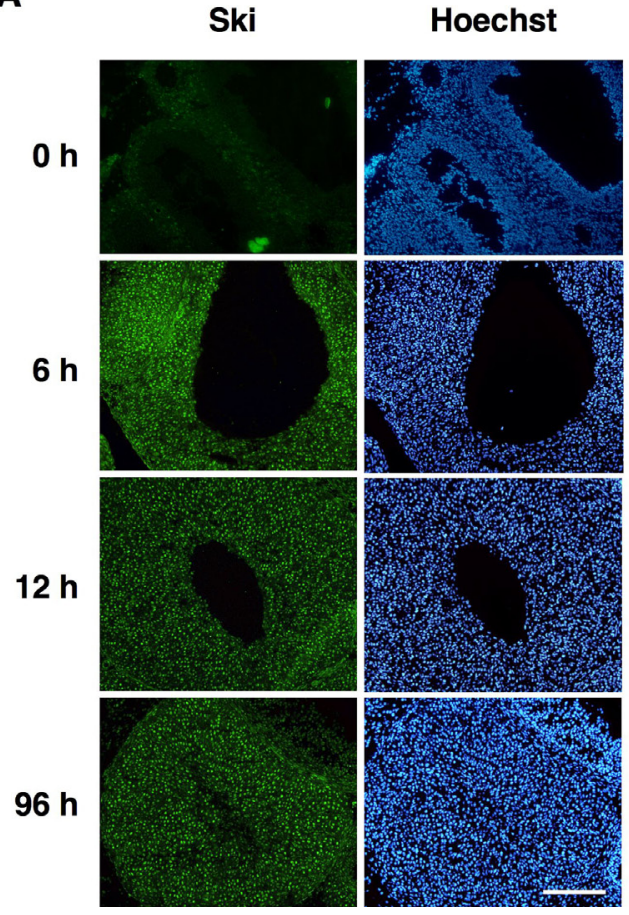

B

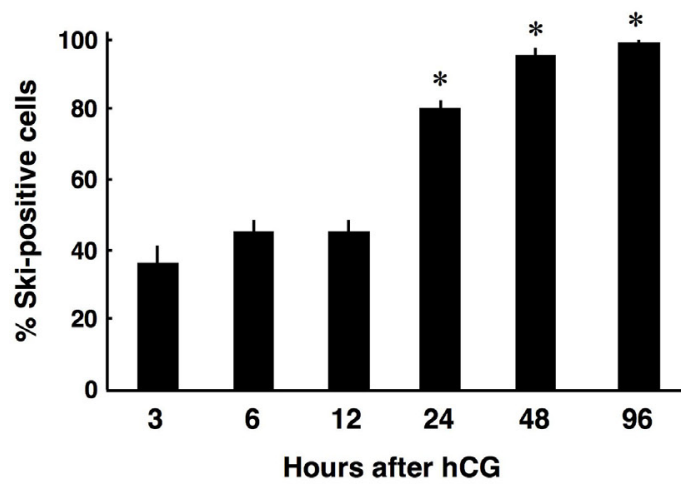

Fig. 2. Immunohistochemical analysis of Ski expression in ovarian sections of eCG/hCG-treated rats. (A) Ski expression was analyzed using a Ski-specific antibody and an Alexa Fluor-conjugated second antibody at the indicated hours (h) after hCG injection. Nuclei were counterstained with Hoechst 33258. Note the absence of Ski-positive granulosa cells in the preovulatory follicle $(0 \mathrm{~h}$ ). Scale bar $=400 \mu \mathrm{m}$. (B) Quantitative analysis of Ski-positive cells. The data are expressed as the percentage of the cell population that is Ski positive. The data are means $\pm \mathrm{SE}$ $(\mathrm{n}=6) . *$ : $<0.05 v s . \mathrm{hCG}$ at 3,6 and $12 \mathrm{~h}$.

follicles [25] and up-regulates FSH receptors and FSH-induced aromatase activity [26, 27]. Apart from activin, BMP-4, BMP-7, BMP-6, BMP-15 and GDF-9 enhance estradiol and inhibin secretion by granulosa cells while suppressing progesterone secretion $[5,6,28]$. After ovulation and during CL formation, inhibin/activin subunit expression is downregulated in most species. A recent study also showed that follicular expression of BMP-2, BMP-3 $\beta$, BMP-4, BMP-6 and BMP-7 is profoundly reduced upon ovulation [29]. These reports suggest that these TGF- $\beta$ family proteins have roles in delaying follicular atresia and/or luteinization. Considering that Ski negatively regulates the activity of TGF- $\beta$ family proteins [17-19], it is therefore possible that Ski, whose expression is induced in granulosa cells in response to LH surge, may favor luteinization by neutralizing the intrafollicular activity of these proteins.

Several studies have indicated that the mRNA transcripts of the Ski gene, $c$-ski, are ubiquitously expressed in many tissues and that $c$-ski mRNA levels remain relatively constant during the cell cycle, differentiation, and embryogenesis [30,31]. The results of the present study, which showed that $c$-ski expression remained unchanged during luteinization of granulosa cells, are in agreement with these reports. We therefore speculated that one possible mechanism by which the Ski protein level might be controlled during luteinization is through regulation by the ubiquitin-proteasome system. Based on the recent findings that degradation of the Ski protein is mediated by an E3 ubiquitin ligase, Arkadia [32], we determined if Arkadia expression changes during luteinization of granulosa cells. The results demonstrated that although Arkadia is indeed expressed in granulosa cells, its expression was unchanged during luteinization. However, this result does not exclude the possibility that Arkadia might be involved in regulating the Ski protein during luteinization of granulosa cells, since we currently have no data regarding Arkadia protein expression due to the unavailability of rat Arkadia-specific antibodies. An alternative possibility is that other ubiquitin ligases, including the Smad ubiquitin regulatory factors, Smurf1 and Smurf2, and the APC/Cdh1 complex [33-36], might regulate Ski protein levels in granulosa cells. Therefore, the mechanism by which the Ski protein expression level is regulated awaits further investigation.

In conclusion, the present study demonstrated that Ski protein expression is induced in granulosa cells upon luteinization, suggesting that Ski is involved in luteinization and in the maintenance of CL function. In addition, this study suggested that the cellular level of the Ski protein is regulated at the posttranscriptional level.

\section{Acknowledgments}

This work was supported by Grants-in-Aid for Scientific Research from the Japan Society for the Promotion of Science. The critical reading of this manuscript by Drs S Ikeda and A Ikeda is greatly appreciated. 


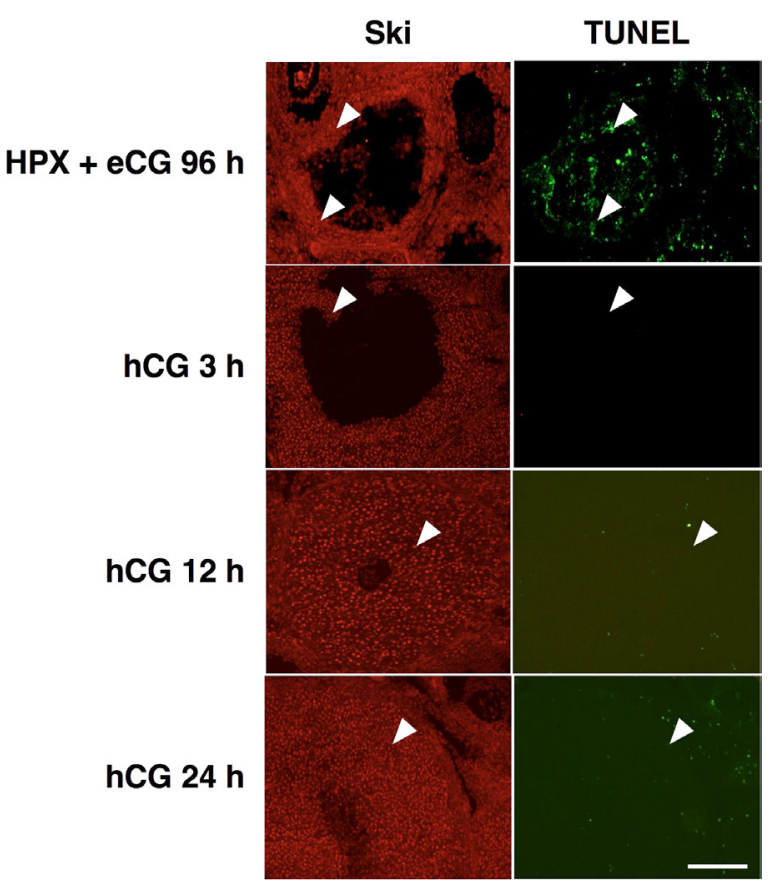

Fig. 3. Ski positive cells do not undergo apoptosis during luteinization. Ovarian sections of eCG/hCG-treated rats were immunohistochemically stained for Ski as described for Fig. 2 and were also analyzed for apoptosis using TUNEL staining. Note that Ski and TUNEL double-positive cells were only present in the atretic follicle (HPX +eCG 96 h). Arrowheads: Ski-positive cells in left photos (Ski) and corresponding cells in right photos (TUNEL). Scale bar $=400 \mu \mathrm{m}$.

\section{References}

1. Roy SK, Hughes J. Ontogeny of granulosa cells in the ovary: lineage-specific expression of transforming growth factor beta 2 and transforming growth factor beta 1 . Biol Reprod 1994; 51: 821-830. [Medline] [CrossRef]

2. Smith MF, McIntush EW, Smith GW. Mechanisms associated with corpus luteum development. J Anim Sci 1994; 72: 1857-1872. [Medline]

3. Espey LL, Richards JS. Temporal and spatial patterns of ovarian gene transcription following an ovulatory dose of gonadotropin in the rat. Biol Reprod 2002; 67: 1662-1670. [Medline] [CrossRef]

4. Richards JS, Hernandez-Gonzalez I, Gonzalez-Robayna I, Teuling E, Lo Y, Boerboom D, Falender AE, Doyle KH, LeBaron RG, Thompson V, Sandy JD. Regulated expression of ADAMTS family members in follicles and cumulus oocyte complexes: evidence for specific and redundant patterns during ovulation. Biol Reprod 2005; 72: 1241-1255. [Medline] [CrossRef]

5. Nilsson EE, Skinner MK. Growth and differentiation factor-9 stimulates progression of early primary but not primordial rat ovarian follicle development. Biol Reprod 2002; 67: 1018-1024. [Medline] [CrossRef]

6. Nilsson EE, Skinner MK. Bone morpfogenetic protein-4 acts as an ovarian follicle survival factor and promotes primordial follicle development. Biol Reprod 2003; 69: 1265-1272. [Medline] [CrossRef]

7. Pehlivan T, Mansour A, Spaczynski RZ, Duleba AJ. Effects of transforming growth factor-alpha and-beta on proliferation and apoptosis of rat theca-interstitial cells. J Endocrinol 2001; 170: 639-645. [Medline] [CrossRef]

8. Knight PG, Glister C. TGF-beta superfamily members and ovarian development. Reproduction 2006; 132: 191-206. [Medline] [CrossRef]

9. Juengel JL, McNatty KP. The role of proteins of the transforming growth factor-beta superfamily in the intraovarian regulation of follicular development. Hum Reprod Update 2005; 11: 143-160. [Medline]

10. Drummond AE, Le MT, Ethier JF, Dyson M, Findlay JK. Expression and localization of localization of activin receptors, Smads, and beta glycan to the postnatal rat
A

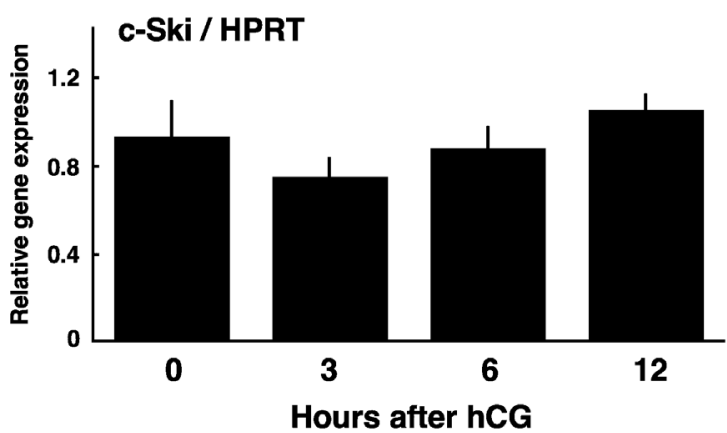

B

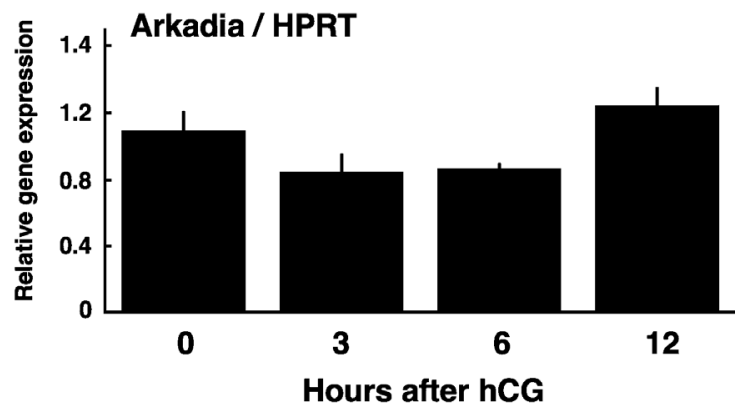

Fig. 4. The mRNA expression of $c$-ski and Arkadia does not change during luteinization. The mRNA expression of $c$-ski (A) and Arkadia (B) was analyzed at the indicated times following hCG injection using qPCR. Data are expressed relative to the expression level of HPRT in each sample. The data are means $\pm \mathrm{SE}(\mathrm{n}=3-4)$ ovary. Endocrinology 2002; 143: 1423-1433. [Medline] [CrossRef]

11. Xu J, Oakley J, McGee EA. Stage-specific expression of Smad2 and Smad3 during folliculogenesis. Biol Reprod 2002; 66: 1571-1578. [Medline] [CrossRef]

12. Li Y, Turck CM, Teumer JK, Stavnezer E. Unique sequence, Ski, in Sloan-Kettering avian retroviruses with properties of a new cell-derived oncogene. J Virol 1986; 57: 1065-1072. [Medline]

13. Stavnezer E, Barkas AE, Brennan LA, Brodeur D, Li Y. Transforming SloanKettering viruses generated from the cloned $\mathrm{v}$-ski oncogene by in vitro and in vivo recombinations. J Virol 1986; 57: 1073-1083. [Medline]

14. Nomura N, Sasamoto S, Ishii S, Date T, Matsui M, Ishizaki R. Isolation of human cDNA clones of Ski and the Ski-related gene, Sno. Nucleic Acids Res 1989; 17 5489-5500. [Medline] [CrossRef]

15. Stavnezer E, Brodeur D, Brennan L. The $v$-Ski oncogene encodes a truncated set of $c$-Ski coding exons with limited sequence and structural relatedness to $v$ - $m y c$. Mol Cell Biol 1989; 9: 4038-4045. [Medline]

16. Sutrave P, Hughes SH. Lsolation and characterization of three distinct cDNAs for the chicken $c$-Ski gene. Mol Cell Biol 1989; 9: 4046-4051. [Medline]

17. Liu X, Sun Y, Weinberg RA, Lodish HF. Ski/Sno and TGF-beta signaling. Cytokine Growth Factor Rev 2001; 12: 1-8. [Medline] [CrossRef]

18. Luo K. Negative regulation of BMP signaling by the ski oncoprotein. $J$ Bone Joint Surg Am 2003; 85-A Suppl 3: 39-43. [Medline]

19. Luo K. Ski and SnoN: negative regulators of TGF-beta signaling. Curr Opin Genet Dev 2004; 14: 65-70. [Medline] [CrossRef]

20. Kim H, Yamanouchi K, Nishihara M. Expression of ski in the granulosa cells of atretic follicles in the rat ovary. J Reprod Dev 2006; 52: 715-721. [Medline] [CrossRef]

21. Bell ET, Lunn SF. The induction of ovulation in immature rats treated with pregnant mares' serum gonadotrophin and human chorionic gonadotrophin. $J$ Exp Physiol Cogn Med Sci 1968; 53: 129-135.

22. Nothnick WB, Curry TE Jr. Divergent effects of interleukin-1 beta on steroidogenesis and matrix metalloproteinase inhibitor expression and activity in cultured rat granulosa cells. Endocrinology 1996; 137: 3784-3790. [Medline] [CrossRef] 
23. Miura R, Noda K, Shiota K, Takahashi M. Changes in 20alpha-hydroxysteroid dehydrogenase mRNA in the ovary of immature rats bearing a single generation of corpora lutea. J Reprod Dev 1992; 38: 249-254. [CrossRef]

24. Nagano Y, Koinuma D, Miyazawa K, Miyazono K. Context-dependent regulation of the expression of $c$-Ski protein by Arkadia in human cancer cells. J Biochem 2010; 147: 545-554. [Medline] [CrossRef]

25. Zhao J, Taverne MA, van der Weijden GC, Bevers MM, van den Hurk R. Effect of activin A on in vitro development of rat preantral follicles and localization of activin A and activin receptor II. Biol Reprod 2001; 65: 967-977. [Medline] [CrossRef]

26. Xiao S, Farnworth PG, Findlay JK. Interation between activin and follicle-stimulating hormone-suppressing protein/follistatin in the regulation of basal inhibin production by cultured rat granulosa cells. Endocrinology 1992; 131: 2365-2370. [Medline] [CrossRef]

27. Xiao S, Robertson DM, Findlay JK. Effects of activin and follicle-stimulating hormone (FSH)-suppressing protein/follistatin on FSH receptors and differentitation of cultured rat granulosa cells. Endocrinology 1992; 131: 1009-1016. [Medline] [CrossRef]

28. McNatty KP, Juengel JL, Reader KL, Lun S, Myllymaa S, Lawrence SB, Western A, Meerasahib MF, Mottershead DG, Groome NP, Ritvos O, Laitinen MP. Bone morphogenetic protein 15 and growth differentiation factor 9 co-operate to regulate granulosa cell function in ruminants. Reproduction 2005; 129: 481-487. [Medline] [CrossRef]

29. Erickson GF, Shimasaki S. The spatiotemporal expression pattern of the bone morphogenetic family in rat ovary cell types during the estrous cycle. Reprod Biol Endocrinol 2003; 1: 9. [Medline] [CrossRef]

30. Grimes HL, Ambrose MR, Goodenow MM. $c$-Skitranscripts with and without exon 2 are expressed in skeletal muscle and throughout chick embryogenesis. Oncogene 1993; 8: 2863-2868. [Medline]

31. Ambrose MR, Bottazzi ME, Goodenow MM. Expression of the $c$-Ski proto-oncogene during cell cycle arrest and myogenic differentiation. DNA Cell Biol 1995; 14: 701-707. [Medline] [CrossRef]

32. Nagano Y, Mavrakis KJ, Lee KL, Fujii T, Koinuma D, Sase H, Yuki K, Isogaya K, Saitoh M, Imamura T, Episkopou V, Miyazono K, Miyazawa K. Arkadia induces degradation of $S n o N$ and $c$-Ski to enhance transforming growth factor-beta signaling. J Biol Chem 2007; 282: 20492-20501. [Medline] [CrossRef]

33. Kavsak P, Rasmussen RK, Causing CG, Bonni S, Zhu H, Thomsen GH, Wrana JL. Smad7 binds to Smurf2 to form an E3 ubiquitin ligase that targets the TGF beta receptor for degradation. Mol Cell 2000; 6: 1365-1375. [Medline] [CrossRef]
34. Ebisawa T, Fukuchi M, Murakami G, Chiba T, Tanaka K, Imamura T, Miyazono K. Smurf1 interacts with transforming growth factor-beta type I receptor through Smad7 and induces receptor degradation. J Biol Chem 2001; 276: 12477-12480. [Medline] [CrossRef]

35. Episkopou V, Arkell R, Timmons PM, Walsh JJ, Andrew RL, Swan D. Induction of the mammalian node requires Arkadia function in the extraembryonic lineages. Nature 2001; 410: 825-830. [Medline] [CrossRef]

36.Hanyu A, Ishidou Y, Ebisawa T, Shimanuki T, Imamura T, Miyazono K. The N domain of Smad7 is essential for specific inhibition of transforming growth factor-beta signaling. J Cell Biol 2001; 155: 1017-1027. [Medline] [CrossRef]

37. Enders AC. Observations on the fine structure of lutein cells. J Cell Biol 1962; 12: 101-113. [Medline] [CrossRef]

38. Meyer GT, Bruce NW. Quantitative cell changes and vascularisation in the early corpus luteum of the pregnant rat. Anatomical Record 1980; 197: 369-374. [Medline] [CrossRef]

39. Rodgers RJ, O'Shea JD, Bruce NW. Morphometric analysis of the cellular composition of the ovine corpus luteum. $J$ Anat 1984; 138: 757-770. [Medline]

40. O'Shea JD, Rodgers RJ, D'Occhio MJ. Cellular composition of the corpus luteum of the cow. J Reprod Fertil 1989; 85: 483-487. [Medline] [CrossRef]

41. Nelson SE, McLean MP, Jayatilak PG, Gibori G. Isolation, characterization, and culture of cell subpopulations forming the pregnant rat corpus luteum. Endocrinology 1992; 130: 954-966. [Medline] [CrossRef]

42. Brännström M, Giesecke L, Moore IC, van den Heuvel CJ, Robertson SA. Leukocyte subpopulations in the rat corpus luteum during pregnancy and pseudopregnancy. Biol Reprod 1994; 50: 1161-1167. [Medline] [CrossRef]

43. Matsuyama S, Takahashi M. Immunoreactive (ir)-transforming growth factor (TGF)-beta in rat corpus luteum: ir-TGF beta is expressed by luteal macrophages. Endocr J 1995; 42: 203-217. [Medline] [CrossRef]

44. Matsuyama S, Shiota K, Tachi C, Nishihara M, Takahashi M. Splenic macrophages enhance prolactin and luteinizing hormone action in rat luteal cell cultures. Endocrinol Jpn 1992; 39: 51-57. [Medline] [CrossRef]

45. Yamanouchi K, Matsuyama S, Nishihara M, Shiota K, Tachi C, Takahashi M. Splenic macrophages enhance prolactin-induced progestin secretion from mature rat granulosa cells in vitro. Biol Reprod 1992; 46: 1109-1113. [Medline] [CrossRef]

46. Ueki N, Zhang L, Hayman MJ. Ski can negatively regulates macrophage differentiation through its interaction with PU.1. Oncogene 2008; 27: 300-307. [Medline] [CrossRef] 